\title{
Viabilitas Benih Melon (Cucumis Melo L.) pada Kondisi Optimum dan Sub-Optimum Setelah Diberi Perlakuan Invigorasi
}

\author{
Viability of Invigorated Melon (Cucumis melo L.) Seed in Optimum and Sub-optimum Conditions
}

\author{
Novita, Faiza C. Suwarno*
}

Departemen Agronomi dan Hortikultura, Fakultas Pertanian, Institut Pertanian Bogor (Bogor Agricultural University), Jl. Meranti, Kampus IPB Darmaga, Bogor 16680, Indonesia Telp.\&Faks.62-251-8629353 e-mail agronipb@indo.net.id

*)Penulis untuk korespondensi : faizasuwarno@yahoo.com

Disetujui 24 Desember 2013/ Published online 13 Februari 2014

\begin{abstract}
The purpose of this research was to find out the effect of invigoration treatments using $\mathrm{GA}_{3}$ and coconut water on viability of high and low quality melon seeds in optimum and sub-optimum (drought) conditions. The research was conducted in Seed Science and Technology Laboratory, Bogor Agricultural University, from February until December 2012. The research was consist of two experiments, invigoration in optimum condition and sub-optimum (drought) condition. The experiments were arranged in a Randomized Completely Block Design with two factors and three replications. The first factor was seed quality i.e low quality and high quality with $60 \%-75 \%$ and $80 \%-95 \%$ germination percentage respectively. The second factor was invigoration treatment (control, coconut water, GA 30 ppm, GA3 100 ppm, combination of coconut water and $G A_{3} 80 \mathrm{ppm}$, and combination coconut water and $G A_{3} 100 \mathrm{ppm}$ ). Variables observed were vigor index, germination percentage, speed of germination, the maximum grow potential and dry weight of normal seedling. Results of the experiment showed that in optimum condition all of invigoration treatment could increase vigor index from $16.67 \%$ to $30.67 \%-48 \%$ except $\mathrm{GA}_{3} 100 \mathrm{ppm}$ treatment. Coconut water treatment could increase germination percentage of low quality melon seed from $72 \%$ to $85.33 \%-88 \%$. In sub-optimum condition there were no invigoration treatment could increase viability of melon seeds.
\end{abstract}

Key word: $G A_{3}$, coconut water, drought condition, invigoration

\section{ABSTRAK}

Penelitian ini bertujuan untuk mengetahui pengaruh perlakuan invigorasi dengan menggunakan $\mathrm{GA}_{3}$ dan air kelapa pada benih melon yang memiliki viabilitas rendah dan tinggi di kondisi optimum dan sub-optimum (kekeringan). Penelitian ini dilakukan di Laboratorium Ilmu dan Teknologi Benih, Institut Pertanian Bogor dari bulan Februari hingga Desember 2012. Penelitian ini terdiri dari dua percobaan yaitu percobaan invigorasi pada kondisi optimum dan percobaan invigorasi pada kondisi sub-optimum. Setiap percobaan disusun dalam Rancangan Kelompok Lengkap Teracak (RKLT) dengan 2 faktor dan 3 ulangan. Faktor yang pertama yaitu tingkat viabilitas, daya berkecambah rendah (60\%-75\%) dan daya berkecambah tinggi (80\%-95\%). Faktor yang kedua adalah perlakuan invigorasi (kontrol, air kelapa, GA 80 ppm, GA 100 ppm, kombinasi air kelapa dan $G A_{3} 80$ ppm dan kombinasi air kelapa dan $G A_{3} 100$ ppm). Variabel yang diamati adalah indeks vigor, daya berkecambah, kecepatan tumbuh, potensi tumbuh maksimum dan berat kering kecambah normal. Hasil dari percobaan menunjukkan bahwa pada kondisi optimum semua perlakuan invigorasi dapat meningkatkan indeks vigor dari $16.67 \%$ menjadi $30.67 \%-48 \%$ kecuali perlakuan $\mathrm{GA}_{3} 100$ ppm. Perlakuan dengan $\mathrm{GA}_{3} 80 \mathrm{ppm}$ dan $\mathrm{GA}_{3} 100 \mathrm{ppm}$ mampu meningkatkan daya berkecambah benih melon tingkat viabilitas rendah dari $72 \%$ menjadi $85.33 \%$ dan $88 \%$. Pada kondisi suboptimum semua perlakuan invigorasi tidak mampu meningkatkan viabilitas benih melon.

Kata kunci : $G A_{3}$, air kelapa, kondisi kekeringan, invigorasi 


\section{PENDAHULUAN}

Melon (Cucumis melo L) merupakan salah satu komoditas hortikultura yang sering dikonsumsi oleh masyarakat. Melon merupakan tanaman buah-buahan semusim yang mempunyai rasa manis, tekstur daging buah yang renyah, warna daging buah yang bervariasi dan mempunyai aroma yang khas. Melon juga mempunyai nilai ekonomi yang tinggi dalam pemasaran dan produksi benihnya. Buah melon tergolong dalam famili Cucurbitaceae dan genus Cucumis (Ghebrestinsae et al. 2007).

Berdasarkan data Direktorat Budidaya dan Pascapanen Buah (2011), konsumsi buah melon di Indonesia saat ini baru mencapai 34.06 $\mathrm{kg} / \mathrm{kapita} / \mathrm{tahun}$, sedangkan tingkat konsumsi perkapita yang direkomendasikan FAO adalah sebesar $65 \mathrm{~kg}$ buah/kapita/tahun. Menurut Badan Pusat Statistik (2011) produksi melon nasional tahun 2010 adalah 85161 ton. Produksi tahun 2009 sebesar 85860 ton, sehingga angka produksi pada tahun 2009 mengalami penurunan pada tahun 2010.

Faktor yang mempengaruhi produksi melon adalah vigor benih. ISTA (2008) mendefinisikan vigor sebagai sekumpulan sifat yang dimiliki benih yang menentukan tingkat potensi aktivitas dan performa benih atau lot benih selama perkecambahan dan munculnya kecambah. Pengujian vigor pada suatu benih sangat diperlukan untuk mendapatkan informasi mutu benih. Benih yang tersebar pada petani mempunyai vigor rendah dan vigor tinggi. Tersebarnya benih yang bervigor rendah dan yang tinggi itu dapat mempengaruhi produktivitas tanaman tersebut. Peningkatan vigor tersebut dikenal sebagai invigorasi.

Berbagai teknik invigorasi telah banyak dilaporkan mampu memperbaiki viabilitas pada benih yang telah mengalami kemunduran dan meningkatkan vigor benih pada kondisi suboptimum. Matriconditioning benih dengan menggunakan serbuk gergaji, $\mathrm{GA}_{3}$ dan serbuk gergaji $+\mathrm{GA}_{3}$ mampu meningkatkan persentase daya berkecambah, indeks vigor dan kecepatan tumbuh serta mampu mengurangi kebocoran elektrolit pada benih cabai, khususnya pada benih vigor sedang (Ilyas et al. 2002).

Ada beberapa senyawa yang sering digunakan untuk invigorasi yaitu Polyethylene glycol (PEG), $\mathrm{KNO}_{3}, \mathrm{~K}_{3} \mathrm{PO}_{4}, \mathrm{KH}_{2} \mathrm{PO}_{4}, \mathrm{MgSO}_{4}$, $\mathrm{NaCl}$, gliserol dan manitol. Penelitian pengaruh invigorasi benih melon dengan GA3 dan air kelapa terhadap vigor melon belum banyak dilakukan. Perlakuan invigorasi pada benih melon diharapkan dapat meningkatkan vigor benih. Beberapa penelitian telah membuktikan mamfaat invigorasi pada tanaman pertanian seperti benih padi (Belo 2012).

Salah satu zat pengatur tumbuh (ZPT) alami yang pernah digunakan untuk perlakuan invigorasi adalah air kelapa. Hasil penelitian Sujarwati et al. (2011) menunjukkan bahwa konsentrasi $75 \%$ air kelapa dapat meningkatkan persentase perkecambahan sebesar $96.25 \%$. Air kelapa muda mengandung sitokinin yang berperan dalam pembelahan sel.

PEG sebagai komponen seleksi pada berbagai jenis tanaman dapat menurunkan pertumbuhan tanaman sekaligus dapat menghasilkan genotipe baru yang tahan terhadap cekaman kekeringan (Hutami 2006). Senyawa PEG dengan berat molekul 6000 dipilih karena mampu bekerja lebih baik pada tanaman daripada PEG dengan berat molekul yang lebih rendah, senyawa PEG mampu mengikat air. Besarnya kemampuan larutan PEG dalam mengikat air bergantung pada berat molekul dan konsentrasinya.

Penelitian ini bertujuan untuk mengetahui pengaruh perlakuan $\mathrm{GA}_{3}$ dan air kelapa terhadap vigor dan viabilitas benih melon pada kondisi optimum dan sub-optimum (kekeringan).

\section{BAHAN DAN METODE}

Penelitian ini dilaksanakan di Laboratorium Ilmu dan Teknologi Benih. Departemen Agronomi dan Hortikultura, Fakultas Pertanian, Institut Pertanian Bogor. Penelitian dimulai bulan Februari sampai Desember 2012.

Bahan yang digunakan adalah benih melon varietas Action. Bahan lain yang digunakan adalah kertas merang, plastik, PEG-6000 (polyethylene Glycol) dengan tekanan -2.0 bar yang setara dengan $126.06 \mathrm{~g} / \mathrm{L}$, air, air kelapa muda, etanol 96\%, giberelin, kertas label, amplop dan selotip. Alat-alat yang digunakan, yaitu alat pengepres kertas tipe IPB 75-1, alat pengecambah benih (APB) tipe IPB 72-1, lemari es, kipas angin, timbangan analitik, magnetic stirrer, oven, desikator, kain strimin, gelas ukur, kamera, kuas, dan streples.

Penelitian ini terdiri atas dua percobaan, yaitu percobaan invigorasi yang ditanam pada kondisi optimum dan percobaan invigorasi yang ditanam pada kondisi sub-optimum. Masingmasing percobaan menggunakan Rancangan Kelompok Lengkap Teracak (RKLT) dengan dua 
faktor dan tiga ulangan. Faktor yang pertama yaitu tingkat viabilitas, daya berkecambah rendah $(60 \%$ - 75\%) dan daya berkecambah tinggi (80\% 95\%). Faktor yang kedua adalah perlakuan invigorasi (kontrol, air kelapa, $\mathrm{GA}_{3} 80 \mathrm{ppm}, \mathrm{GA}_{3}$ 100 ppm, kombinasi air kelapa dan $\mathrm{GA}_{3} 80 \mathrm{ppm}$ dan kombinasi air kelapa dan $\mathrm{GA}_{3} 100$ ppm). Setiap ulangan terdiri dari 25 butir benih.

\section{Invigorasi Benih yang Ditanam pada Kondisi Optimum}

Pada percobaan ini benih melon dari dua tingkat viabilitas (tinggi $(80 \%-95 \%)$ dan rendah $60 \%-75 \%$ )) diberi perlakuan invigorasi (kontrol, air kelapa, $\mathrm{GA}_{3} 80$ ppm, $\mathrm{GA}_{3} 100$ ppm, kombinasi air kelapa dan $\mathrm{GA}_{3} 80 \mathrm{ppm}$ dan kombinasi air kelapa dan $\mathrm{GA}_{3} 100 \mathrm{ppm}$ ). Perendaman dilakukan pada suhu $10^{\circ} \mathrm{C}$ selama 24 jam.

Setelah selesai direndam kemudian benih dikeringanginkan selama 24 jam. Benih yang sudah kering ditanam pada media kertas merang yang menggunakan metode Uji Kertas digulung didirikan dalam Plastik (UKDdP). Pada kondisi optimum kertas merang dilembabkan dengan air dan di pres dengan menggunakan alat pengepres kertas merang.

Peubah yang diamati pada percobaan ini adalah indeks vigor (IV), daya berkecambah (DB), kecepatan tumbuh $\left(\mathrm{K}_{\mathrm{CT}}\right)$ dan potensi tumbuh maksimum (PTM).

\section{Percobaan Invigorasi yang Ditanam pada} Kondisi Sub-optimum

Pada percobaan ini benih dari dua tingkat viabilitas (tinggi (80\%-95\%) dan rendah 60\%75\%)) diberi perlakuan yang sama dengan perlakuan pada kondisi optimum. Kemudian ditanam pada media kertas merang yang telah dilembabkan dengan menggunakan PEG 6000 dengan tekanan osmotik -2 bar.

Peubah yang diamati pada percobaan ini adalah indeks vigor (IV), daya berkecambah (DB), kecepatan tumbuh $\left(\mathrm{K}_{\mathrm{CT}}\right)$ dan potensi tumbuh maksimum (PTM). Setiap percobaan dilakukan analisis ragam dan uji lanjut yang digunakan terhadap hasil yang berpengaruh nyata adalah Duncans Multiple Test (DMRT) pada taraf nyata 5\% (Gomez dan Gomez 1995).

\section{HASIL DAN PEMBAHASAN}

Percobaan I : Pengaruh Perlakuan Invigorasi terhadap Viabilitas Benih Melon yang Ditanam pada Kondisi Optimum

Sidik ragam pada Tabel 1 menunjukkan bahwa tingkat viabilitas pada kondisi optimum berpengaruh sangat nyata terhadap semua tolok ukur yang diamati kecuali tolok ukur kecepatan tumbuh berpengaruh nyata. Perlakuan invigorasi pada kondisi optimum berpengaruh sangat nyata terhadap tolok ukur indeks vigor. Perlakuan invigorasi menunjukkan pengaruh tidak nyata terhadap daya berkecambah, kecepatan tumbuh dan potensi tumbuh maksimum.

Tabel 1. Rekapitulasi hasil analisis pengaruh tingkat viabilitas, perlakuan invigorasi dan interaksinya terhadap viabilitas benih melon pada kondisi optimum.

\begin{tabular}{|c|c|c|c|}
\hline \multirow[t]{2}{*}{ Tolok Ukur } & \multicolumn{3}{|c|}{ Perlakuan dan interaksi } \\
\hline & TV & I & TVxI \\
\hline Indeks Vigor & $* *$ & $* *$ & tn \\
\hline \multirow{2}{*}{$\begin{array}{l}\text { Daya } \\
\text { Berkecambah }\end{array}$} & $* *$ & tn & $*$ \\
\hline & & & \\
\hline Kecepatan & \multicolumn{2}{|c|}{ Tumbuh } & tn \\
\hline \multicolumn{3}{|l|}{ Maksimum } & tn \\
\hline Keterangan : & $\begin{array}{l}\text { (ti } \\
\text { igora } \\
\text { gat } n y \\
\text { benga } \\
\text { f } 1 \%\end{array}$ & at & $\begin{array}{l}\text { itas), I } \\
\text { pengaruh } \\
5 \%, * *= \\
\text { ata pada } \\
\text { pengaruh }\end{array}$ \\
\hline
\end{tabular}

Interaksi antara tingkat viabilitas dan invigorasi tidak bepengaruh nyata pada semua tolok ukur, kecuali terhadap tolok ukur daya berkecambah.

Pengaruh Interaksi Tingkat Viabilitas dan
Perlakuan Invigorasi terhadap Daya
Berkecambah pada Kondisi Optimum

Daya berkecambah merupakan tolok ukur viabilitas benih yang paling banyak digunakan dalam pengujian mutu benih. Menurut Ilyas (2012) viabilitas benih merupakan daya hidup benih, aktif secara metabolis, dan memiliki enzim yang dapat mengatalisis reaksi metabolis yang diperlukan untuk perkecambahan dan pertumbuhan kecambah. 
Tabel 2. Pengaruh interaksi tingkat viabilitas dan perlakuan invigorasi pada kondisi optimum terhadap tolok ukur daya berkecambah $(\%)$

\begin{tabular}{llll}
\hline \multirow{2}{*}{ Perlakuan } & \multicolumn{2}{c}{ Tingkat viabilitas } & \multirow{2}{*}{ Rata - rata } \\
\cline { 2 - 3 } & TV 1 & TV 2 & $83.33 \mathrm{AB}$ \\
Kontrol & $94.67 \mathrm{ab}$ & $72.00 \mathrm{e}$ & $86.67 \mathrm{~A}$ \\
Air kelapa & $98.67 \mathrm{a}$ & $74.67 \mathrm{de}$ & $89.33 \mathrm{~A}$ \\
$\mathrm{GA}_{3} 80 \mathrm{ppm}$ & $93.33 \mathrm{ab}$ & $85.33 \mathrm{bcd}$ & $87.33 \mathrm{~A}$ \\
$\mathrm{GA}_{3} 100 \mathrm{ppm}$ & $86.67 \mathrm{abcd}$ & $88.00 \mathrm{abc}$ & $78.00 \mathrm{~B}$ \\
Air kelapa+GA & $85.33 \mathrm{bcd}$ & $70.67 \mathrm{e}$ & $84.67 \mathrm{AB}$ \\
Air kelapa+GA $100 \mathrm{ppm}$ & $89.33 \mathrm{abc}$ & $80.00 \mathrm{cde}$ & \\
\hline Rata - rata & $91.333 \mathrm{~A}$ & $78.44 \mathrm{~B}$ & \\
\hline
\end{tabular}

Keterangan : angka-angka yang diikuti huruf kecil yang sama tidak berbeda nyata pada uji DMRT $\alpha=0.05$. TV $1=$ tingkat viabilitas tinggi. TV $2=$ tingkat viabilitas rendah.

Pada TV1 semua perlakuan tidak memberikan pengaruh dalam meningkatkan daya berkecambah benih. Secara statistik semua perlakuan tidak berpengaruh nyata terhadap daya berkecambah. Pada TV2 perlakuan $\mathrm{GA}_{3} 80 \mathrm{ppm}$ dan $\mathrm{GA}_{3} 100 \mathrm{ppm}$ memperlihatkan peningkatan vigor dari $72 \%$ menjadi $85.33 \%$ dan $88 \%$. Giberelin merupakan senyawa organik yang berperan penting dalam proses perkecambahan, karena dapat mengaktifkan reaksi enzimatik di dalam benih.

Menurut Kucera et al. (2005) ada dua fungsi giberelin selama perkecambahan benih yaitu, pertama giberelin diperlukan untuk meningkatkan potensi tumbuh embrio dan sebagai promotor perkecambahan, dan kedua diperlukan untuk mengatasi hambatan mekanik oleh lapisan penutup benih karena terdapatnya jaringan di sekeliling radikula.

Pengaruh Tingkat Viabilitas terhadap Beberapa Tolok Ukur yang Diamati

Pada Tabel 3 dapat dilihat bahwa pengaruh tingkat viabilitas terhadap tolok ukur indeks vigor, kecepatan tumbuh dan potensi tumbuh maksimum.

Tabel 3. Pengaruh tingkat viabilitas terhadap beberapa tolok ukur yang diamati pada kondisi optimum

\begin{tabular}{lcc}
\hline \multirow{2}{*}{ Tolok ukur } & \multicolumn{2}{c}{ Tingkat viabilitas } \\
\cline { 2 - 3 } & TV 1 & TV 2 \\
\hline Indeks vigor (\%) & $51.10 \mathrm{a}$ & $21.56 \mathrm{~b}$ \\
Kecepatan tumbuh (\%/etmal) & $26.94 \mathrm{a}$ & $22.49 \mathrm{~b}$ \\
Potensi tumbuh maksimum(\%) & $93.78 \mathrm{a}$ & $87.33 \mathrm{~b}$ \\
\hline
\end{tabular}

Keterangan : angka-angka yang diikuti huruf kecil pada baris yang sama tidak berbeda nyata pada uji DMRT $\alpha=0.05$

Pada semua tolok ukur yang diamati, benih dengan TV1 memiliki nilai yang lebih besar dibandingkan dengan TV2. Hal ini dikarenakan respon benih TV2 terhadap perlakuan invigorasi tidak lebih tinggi dari TV1 sehingga nilai viabilitas TV2 tidak dapat menyamai TV1.
Pengaruh Perlakuan Invigorasi terhadap Indeks Vigor

Pada Tabel 4 dapat dilihat bahwa perlakuan invigorasi pada kondisi optimum berpengaruh nyata terhadap indeks vigor. Benih kontrol yang mempunyai indeks vigor $16.67 \%$ setelah diberikan perlakuan invigorasi air kelapa benih meningkat indeks vigornya menjadi $38 \%$. 
Tabel 4. Pengaruh perlakuan invigorasi terhadap indeks vigor pada kondisi optimum

\begin{tabular}{ll}
\hline Perlakuan Invigorasi & Indeks vigor \\
\hline Kontrol & $16.67 \mathrm{~b}$ \\
Air kelapa & $38.00 \mathrm{a}$ \\
$\mathrm{GA}_{3} 80 \mathrm{ppm}$ & $39.33 \mathrm{a}$ \\
$\mathrm{GA}_{3} 100 \mathrm{ppm}$ & $30.67 \mathrm{ab}$ \\
Air kelapa+ $\mathrm{GA}_{3} 80 \mathrm{ppm}$ & $45.33 \mathrm{a}$ \\
Air kelapa+GA $100 \mathrm{ppm}$ & $48.00 \mathrm{a}$ \\
\hline Keterangan : angka-angka yang diikuti huruf kecil pada baris yang sama tidak berbeda nyata pada uji DMRT $\alpha=0.05$
\end{tabular}

Peningkatan indeks vigor diduga karena air kelapa mengandung senyawa yang berfungsi untuk merangsang pembentukan akar dan daun. Air kelapa juga mengandung $4.11 \%$ karbohidrat, $0.13 \%$ protein dan $0.12 \%$ lemak. Air kelapa mengandung tiga hormon yang dibutuhkan dalam perkecambahan antara lain sitokinin, auksin dan giberelin. Perlakuan $\mathrm{GA}_{3} \quad 80 \mathrm{ppm}$ mampu meningkatkan indeks vigor benih menjadi $39.33 \%$ dari indeks vigor kontrol $16.67 \%$. $\mathrm{GA}_{3}$ dengan konsentrasi $80 \mathrm{ppm}$ merupakan perlakuan yang tepat untuk tolok ukur indeks vigor karena peningkatan konsentrasi $\mathrm{GA}_{3}$ menjadi 100 ppm justru menjadikan tidak berbeda nyata dengan kontrol. Perlakuan kombinasi antara $\mathrm{GA}_{3} 80 \mathrm{ppm}$ dan $100 \mathrm{ppm}$ dengan air kelapa mampu meningkatkan indeks vigor benih dari $16.67 \%$ menjadi $45.33 \%-48 \%$.

Pada perbanyakan anggrek Dendrobium secara kultur jaringan, pemberian air kelapa 150 $\mathrm{ml} / \mathrm{l}$ dapat mendorong pertumbuhan planlet
(Widiastoety et al. 1997). Air kelapa dapat memacu pertumbuhan benih karena mengandung hormon pertumbuhan yang sangat diperlukan saat fase perkecambahan.

Percobaan II : Pengaruh Perlakuan Invigorasi terhadap Viabilitas Benih Melon pada Kondisi Sub-optimum

Kondisi sub-optimum adalah kondisi yang kurang optimum bagi perkecambahan benih. Kondisi sub-optimum meliputi cekaman kekeringan, tanah salin dan lain-lain. Pada percobaan ini kondisi sub-optimum adalah cekaman kekeringan yang menggunakan larutan PEG 6000 -2 bar. Hasil sidik ragam pada Tabel 5 menunjukkan bahwa tingkat viabilitas pada kondisi sub-optimum berpengaruh sangat nyata terhadap semua tolok ukur.

Tabel 5. Rekapitulasi hasil analisis pengaruh tingkat viabilitas, perlakuan invigorasi dan interaksinya terhadap viabilitas benih melon pada kondisi sub-optimum

\begin{tabular}{llll}
\hline Tolok Ukur & \multicolumn{3}{c}{ Perlakuan dan interaksi } \\
\cline { 2 - 4 } & TV & I & TVxI \\
\hline Daya Berkecambah & $* *$ & tn & tn \\
Kecepatan Tumbuh & $* *$ & tn & tn \\
Potensi Tumbuh Maksimum & $* *$ & tn & tn \\
\hline
\end{tabular}

Keterangan : TV (tingkat viabilitas), I (invigorasi), $*=$ berpengaruh sangat nyata pada taraf $5 \%, * *=$ berpengaruh sangat nyata pada taraf $1 \%, \mathrm{tn}=$ tidak berpengaruh nyata.

Perlakuan invigorasi pada kondisi suboptimum tidak berpengaruh nyata untuk semua tolok ukur yang diamati. Pengaruh interaksi antara tingkat viabilitas dan invigorasi berpengaruh tidak nyata terhadap daya berkecambah, kecepatan tumbuh, potensi tumbuh maksimum dan berat kering kecambah normal.

\section{Pengaruh Tingkat Viabilitas Terhadap Tolok Ukur yang diamati}

Pada Tabel 6 dapat dilihat pengaruh tingkat viabilitas benih melon terhadap tolok ukur daya berkecambah, kecepatan tumbuh maksimum dan potensi tumbuh maksimum. Pada kondisi suboptimum semua tolok ukur yang diamati menunjukkan nilai TV2 berbeda nyata dengan TV1. 
Tabel 6. Pengaruh tingkat viabilitas terhadap beberapa tolok ukur pada kondisi sub-optimum

\begin{tabular}{lcc}
\hline \multirow{2}{*}{ Tolok ukur } & \multicolumn{2}{c}{ Tingkat viabilitas } \\
\cline { 2 - 3 } & TV 1 & TV 2 \\
\hline Daya Berkecambah & $85.78 \mathrm{a}$ & $64.22 \mathrm{~b}$ \\
Kecepatan tumbuh & $20.51 \mathrm{a}$ & $14.62 \mathrm{~b}$ \\
Potensi tumbuh maksimum & $93.56 \mathrm{a}$ & $85.33 \mathrm{~b}$ \\
\hline
\end{tabular}

Keterangan : angka-angka yang diikuti huruf kecil pada baris yang sama tidak berbeda nyata pada uji DMRT $\alpha=0.05$

Pada pengamatan indeks vigor belum ada benih melon yang berkecambah normal. Benihbenih yang tidak tumbuh diduga karena aktivitas dari PEG yang menyebabkan jumlah air yang terserap melalui permukaan kulit benih melon sangat sedikit dan lambat, sehingga benih tersebut baru terlihat tumbuh menjadi kecambah normal pada pengamatan hari kelima (saat pengamatan daya berkecambah).

Tabel 7. Pengaruh perlakuan invigorasi terhadap daya berkecambah, kecepatan tumbuh maksimum dan berta kering kecambah normal pada kondisi sub-optimum

\begin{tabular}{rccccccc}
\hline \multirow{2}{*}{ tolok ukur } & Tingkat & \multicolumn{7}{c}{ Perlakuan } \\
\cline { 3 - 8 } & viabilitas & I0 & I1 & I2 & I3 & I4 & I5 \\
\hline \multirow{2}{*}{ Daya Berkecambah } & TV1 & 82.67 & 80 & 86.67 & 92 & 88 & 85.33 \\
& TV2 & 58.67 & 58.67 & 70.67 & 72 & 58.67 & 66.67 \\
Kecepatan Tumbuh & TV1 & 19.67 & 19.13 & 21 & 22.2 & 21.2 & 9.87 \\
& TV2 & 13.2 & 13.6 & 16.8 & 16.13 & 13.46 & 14.53 \\
\hline
\end{tabular}

Pada kondisi sub-optimum benih melon mendapatkan sedikit air untuk melakukan proses perkecambahan. Hal ini disebabkan karena penggunaan larutan PEG -2 bar menyebabkan penyerapan air yang sedikit dan lambat oleh benih melon. PEG sebagai komponen seleksi pada berbagai jenis tanaman dapat menurunkan pertumbuhan tanaman sekaligus dapat menghasilkan genotipe-genotipe baru yang tahan terhadap cekaman kekeringan (Hutami 2006). Penyerapan air yang sedikit dan lambat berakibat pada tolok ukur yang diamati.

\section{KESIMPULAN}

Pada kondisi optimum semua perlakuan invigorasi kecuali $\mathrm{GA}_{3} 100 \mathrm{ppm}$ dapat meningkatkan indeks vigor benih melon. Perlakuan invigorasi dengan menggunakan $\mathrm{GA}_{3}$ $80 \mathrm{ppm}$ dan $100 \mathrm{ppm}$ mampu meningkatkan daya berkecambah benih melon tingkat viabilitas rendah sehingga setara dengan tingkat viabilitas tinggi. Perlakuan air kelapa dan kombinasi antara air kelapa dan $\mathrm{GA}_{3}$ baik pada tingkat viabilitas

\section{Pengaruh Perlakuan Invigorasi terhadap Daya Berkecambah dan Kecepatan Tumbuh}

Pada Tabel 7 menunjukkan bahwa semua perlakuan tidak berpengaruh nyata terhadap tolok ukur daya berkecambah dan kecepatan tumbuh. rendah maupun tinggi tidak dapat meningkatkan viabilitas benih melon.

Pada kondisi sub-optimum semua perlakuan invigorasi tidak mampu meningkatkan viabilitas benih melon berdasarkan semua tolok ukur yang diamati yaitu daya berkecambah, indeks vigor, kecepatan tumbuh, potensi tumbuh maksimum dan berat kering kecambah normal.

\section{DAFTAR PUSTAKA}

[ISTA] International Seed Testing Association. 2008. Seed Science and Technology. International Rules for Seed Testing. Zurich: International Seed Testing Association.

Badan Pusat Statistik. 2011. Perkembangan Beberapa Indikator Utama SosialEkonomi Indonesia. Jakarta (ID): Badan Pusat Statistik. 182 hal.

Belo, S.M. 2012. Pengaruh Perlakuan Invigorasi terhadap Viabilitas Benih dan Hasil Padi (Oryza sativa L.) [Disertasi]. Bogor (ID): 
Program Pascasarjana, Institut Pertanian Bogor.

Ghebretinsae, A.G., M. Thulin, J.C. Barber. 2007. Relationship of cucumber and melons unraveled: molecular phylogenetics of cucumis and related genera (benincaseae, cucurbitaceae). American Journal of Botany 94 (7):1256-1266.

Gomez, K.A., Gomez A.A. 1995. Prosedur Statistik untuk Penelitian Pertanian (diterjemahkan dari : Statistical Procedurs for Agricultural Research, Penerjemah : E, Sjamsuddin dan J.S. Baharsjah). Penerbit Universitas Indonesia. Jakarta (ID). 698 hal.

Hutami, S., Mariska I., Supriat Y. 2006. Peningkatan Keragaman Genetik Tanaman melalui Keragaman Somaklonal. Jurnal AgroBiogen 2(2):8188.
Ilyas, S. 2012. Ilmu dan Teknologi Benih. Bogor (ID): IPB Pr.

Ilyas, S, G.A.K. Sutariati, Faiza C.S., Sudarsono. 2002. Matriconditioning improves the quality and protein level of medium vigor hot pepper seed. Seed Technology. 24(1):65-75.

Kucera, B., M.A. Cohn, G.H. Metzger. 2005. Plant hormone interactions during seed dormancy release and germination. Seed Science Research. 15:281-307.

Sujarwati, Fathonah S., Johani E., Herlina. 2011. Penggunaan air kelapa untuk meningkatkan perkecambahan dan pertumbuhan palem putri (Veitchia merillii). Jurnal Sagu 1:24-28

Widyastoety, D.S., Kusumo S., Syafni. 1997. Pengaruh tingkat ketuaan air kelapa dan jenis kelapa terhadap pertumbuhan planlet anggrek dendrobium. Jurnal Hortikultura 7(3):768-772. 